\title{
Local Wisdom of Gapura in Sunan Ampel Mosque based on the Place Attachment Theory
}

\author{
Prasetyo Wahyudie $^{1,2, *}$, Antariksa ${ }^{3}$, Lisa Dwi Wulandari ${ }^{3}$, Herry Santosa $^{3}$ \\ ${ }^{1}$ Doctoral Program of Civil Engineering Department, Brawijaya University, Malang, Indonesia \\ ${ }^{2}$ Interior Design Department, Institut Teknologi Sepuluh Nopember, Surabaya, Indonesia \\ ${ }^{3}$ Architecture Department, Engineering Faculty, Brawijaya University, Malang, Indonesia
}

Received August 7, 2021; Revised September 22, 2021; Accepted October 17, 2021

\section{Cite This Paper in the following Citation Styles}

(a): [1] Prasetyo Wahyudie, Antariksa, Lisa Dwi Wulandari, Herry Santosa , "Local Wisdom of Gapura in Sunan Ampel Mosque based on the Place Attachment Theory," Civil Engineering and Architecture, Vol. 9, No. 7, pp. 2147-2159, 2021. DOI: 10.13189/cea.2021.090704.

(b): Prasetyo Wahyudie, Antariksa, Lisa Dwi Wulandari, Herry Santosa (2021). Local Wisdom of Gapura in Sunan Ampel Mosque based on the Place Attachment Theory. Civil Engineering and Architecture, 9(7), 2147-2159. DOI: 10.13189/cea.2021.090704.

Copyright $\bigcirc 2021$ by authors, all rights reserved. Authors agree that this article remains permanently open access under the terms of the Creative Commons Attribution License 4.0 International License

\begin{abstract}
Muslims dominate a quarter of the world's population, and Indonesia is one of the most Muslim countries. Java is the island in Indonesia with the most population and is known as the place where Islam is growing. Sunan Ampel, one of Walisongo, succeeds in spreading Islam in Java. Some of the relics of Sunan Ampel, such as the mosque and his neighborhood, become a historical place that many people often visit. The hallmark of his legacy is the gate called Gapura. Many studies have been done about the uniqueness of Gapura; however, none of them focus on the place attachment theory. Thus, this paper proposed the study of the combination between place attachment theory and the uniqueness of Gapura. The data were collected from the survey to the Area of Sunan Ampel. After that, qualitative research with a collaboration of interdisciplinary literature studies has been done to interpret the obtained data. Furthermore, the data will be synthesized and discussed to re-estimating the thought of Sunan Ampel. This study aims to get a holistic understanding of Sunan Ampel and the Gapura in the neighborhood of Sunan Ampel. Thus, the architecture and ornament of Gapura can show the past situation of the neighborhood and the development of Islam in Java. The result shows that the study with place attachment theory gives comprehensive results from the relation between local wisdom and the Gapura. By using the place attachment theory, it can be seen that the ornament during Sunan Ampel Era is similar to the previous Era, which is Majapahit. However, some elements of Islam are added in
\end{abstract}

the Gapura, such as Pillar of Islam or called Rukun Islam. Thus, it can be concluded that there is local wisdom in Gapura of Sunan Ampel mosque related to the place attachment theory, which is believed it becomes a key to the succeed of Sunan Ampel in spreading Islam.

Keywords Gapura, Heritage, Local Wisdom, Ornament, Place Attachment

\section{Introduction}

Indonesia is known as one of the largest Muslim countries in the world [1]. As an archipelagic country with around 56.000 islands, most Indonesian people are live on Java Island. It is shown that around $56.10 \%$ of Indonesian stay in Java, while $21.68 \%$ stay in Sumatra, and $22.22 \%$ are scattered in other islands [2]. Thus, Java is believed can represent the development of Muslims in Indonesia. The development of Islam in Indonesia cannot be separated from the role of Forum Sembilan Wali or called Walisongo [3]. Sunan Ampel is one of the Walisongo who has a significant impact on the development of Islam in Surabaya, East Java. It is shown by the architecture of the mosque and its surrounding environment in Ampel Street, Surabaya.

Ampel Street is located in the Ampel Denta area, Ujung Galuh City, known as Surabaya. The location of Ampel 
Street itself has its own historical story, where the King of Majapahit Kingdom lent the land to Sunan Ampel [4]. Since then, Sunan Ampel built a mosque and Islamic boarding school in that area. Over time, the location is well-known as Ampel Street with Sunan Ampel mosque in it.

The neighborhood of Sunan Ampel is still alive now. Many people come to visit the grave of Sunan Ampel, which is located in Ampel Street. The environment and landscape of the Sunan Ampel neighborhood (including the mosque) can be interpreted as cultural heritage value and can be categorized as historical buildings [5]. Furthermore, there is some research about Sunan Ampel mosque, including the construction, conservation, acculturation, syncretism, expression, and the culture of Sunan Ampel itself [1, 4, 6, 7, 8, 9].

The meaning of the Sunan Ampel mosque has been described by [9]-[11] from the point of view of Majapahit Era. However, they did not explain from Islamic point of view which is more important in the development of the mosque and the surrounding area. For example, the Gapura in Sunan Ampel mosque also plays an important role in spreading Islam besides the mosque itself. Most of researchers thought that Gapura is the only complement of the mosque or a building. The architecture and the ornament of Gapura were only examined for making a replica for a souvenir [8]-[11]. Thus, the study about the Gapura and its meaning are needed in order to enrich the previous study about Sunan Ampel mosque.

Furthermore, this paper proposed a study regarding the unique characteristic of the Gapura in the Sunan Ampel neighborhood. Each Gapura in the Sunan Ampel neighborhood has a unique character than other Gapura from Majapahit Era that makes this study more complicated. Furthermore, research about place attachment is conducted to check the interaction between the Gapura as the local wisdom and the society. The point of view of Sunan Ampel in spreading Islam using the architecture and the ornament becomes one of the points in this research. The society of the Majapahit kingdom is dominated by beliefs in Hindu. However, Sunan Ampel tries to teach a new belief to the society in the Ampel neighborhood. Thus, the study will be more complicated with the addition of spiritual aspect [12] because there is a change of belief from Hindu to Islam.

The local wisdom of Sunan Ampel shows that there is a hereditary culture that is inherent from the Majapahit era to the present. A temple, which shows the holy place for Hindu, is replaced with Gapura for Islam. However, both of them are having a similar shape. It can be seen that the local wisdom in Sunan Ampel mosque is from the Majapahit Era. Furthermore, the Gapura is still be used nowadays. A place attachment theory can be applied to check the relationship between a human and a place. Thus, people will feel different emotions towards the place. People will feel that the place is not just a monument/building but feel that the place has its meaning. Thus, it will make the place more meaningful, and it will be good to remember the meritorious. In this paper, Sunan Ampel is chosen to be the research object because he is the first person whose traces can be traced. The previous Walisongo, such as Sunan Maulana Malik Ibrahim, Sunan Maulana Ishaq, etc. do not have a historical and heritage buildings that represent their legacy. This study only focuses on the explanation of the Gapuras based on Sunan Ampel's thought. For example, Sunan Ampel used five Gapuras to show there being five Pillar of Islam to his students and residents in the surrounding area to do a da'wah. However, there is no further elucidation about the thought of the people in nowadays about the Gapuras.

Accordingly, the remainder of the paper is organized as follows. A brief description of the methods that are used in the paper is articulated in Section 2. Section 3 describes the result of the proposed study, including the place attachment theory, a slight background of Sunan Ampel, and the ornament of each Gapura in the Sunan Ampel neighborhood. Finally, Section 4 concludes the research works and the future works.

\section{Methods}

This study is divided into two parts. The first part is knowing the background of Gapuras in Sunan Ampel's Era. Holistic understanding about the study object is needed for the analysis. This research is conducted based on the previous research on cultural heritage buildings, in the beginning Islamic Era such as mosques. Therefore, a study of religious history before Islam is carried out, and it is also the beginning of Islam Era. A pre-Islamic study related to Gapuras is needed, such as the preliminary of Gapuras. The history of Islam development is also needed to know the background of Gapuras. Furthermore, a study minority psychology in surviving and developing themselves will be done. In this part, the data are collected through a survey, building measurements, taking photos and drawings.

The second part is analyzing Gapuras in the framework of place attachment. In this part, an approach is taken to know how humans understand the message and meaning of the existence Gapuras. There are five steps, such as: 1. Reciting the meaning name of Gapuras, 2. Seeking the characteristics of the shape and ornament of each Gapuras, 3. Getting the meaning of each ornament in the previous Era (Hindu), 4. Getting the new meaning for each ornament from Islamic point of view at that time.

The objective of this paper is to comprehend the legacy of Sunan Ampel as part of the da'wah, which is different from the previous religions and has a minority group. Furthermore, Sunan Ampel try not against the Majapahit Kingdom and the previous religions, so there is no war between Sunan Ampel and King of Majapahit. Place 
attachment theory is used to get the point of view of Sunan Ampel at that time.

\section{Results and Discussion}

To answer the problem and the goal of this research, a discussion about the shape of the Gapura, which is similar to the temple, will be provided. Furthermore, the study about the designation and its ornament will be explained in this section.

\subsection{Place Attachment}

Most experts define place attachment as a multifaceted concept that describes the relationships between people and their important place [13], [14]. Based on Giuliani, Low \& Altman's opinions, Scannell \& Gifford [15] added a relation between place attachment with the human group [13]. As a result, not only individuals but also a group of people are included in place attachment theory. Furthermore, Jorgensen \& Stedman stated that place attachment is inextricably linked to place identity and dependence on the place [15].

Place attachment theory is the development of attachment theory. Place attachment theory began in 1983 with the application of attachment theory by Shumaker and Taylor by linking people to their environment [15]. Shumaker and Taylor emphasize the significance of physical location and social when considering its behavioral and cognitive components. The hypothesis of place attachment was first articulated by Altman and Low in 1992 [14]. Altman has shown that place attachment is made up of a variety of settings (Places), actors (People), and psychological processes (Process) or better known as (P-P-P) models.

Place attachment research has risen since its inception by Shumaker \& Taylor and Altman \& Low. Place attachment theory or its applications have been extensively investigated in many disciplines and have gotten much attention in recent years [15]-[17]. However, research about place attachment continues to take place in parts and independently. Thus, Scannell \& Gifford introduced the place attachment theory model in 2010, which is a refinement of Altman \& Low's approach in 1992.

From a holistic perspective, environmental psychology builds place attachment theory from the Man-Process-Place dimension (tripartite organization) to analyze humans and their surroundings [15], shown in Figure 1. The dimensions are classified as follows:

- The Man dimension is classified into two categories: Individual and Cultural group. Individuals are made up of experiences, realizations, and milestones, whereas cultural groups are made up of religious and historical elements.

- The Place dimension is classified into two categories: Social and Physical. Social comprises of the social arena and social symbol. Physical is made up of both nature and built.

- The Process dimension is classified into three categories: Affect, Cognition, and Behavior. Happiness, pride, and love are examples of Affect, while memory, knowledge, schemas, and meaning are examples of Cognition. Furthermore, Behavior is made up of proximity-maintaining and place reconstruction.

The description shows how place attachment theory evolved from Bowbly's attachment theory, notably the Person-Person relationship. The Person-Place was tested on the built environment by Shumaker. After that, Altman \& Low (1992) revised it into Person-Process-Place and finally developed and mapped by Scannell \& Gifford.

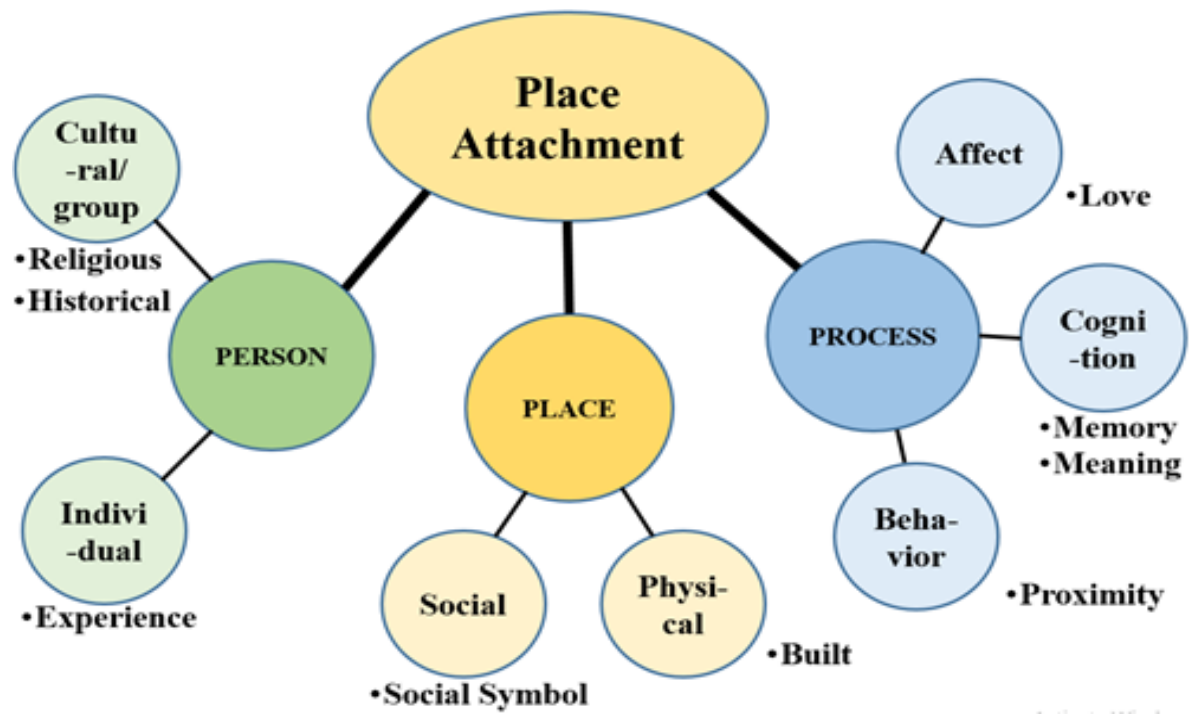

Figure 1. Place attachment model in research based on Scannel [7] 
The Person dimension will lead to anthropology and history. Rapoport [18] presents analytical methods based on historical analysis and cross-cultural analysis to acquire patterns and activities of regular and non-regular cultural behavior in human-environment relations. This method can demonstrate a self-evident attitude toward the environment. On the Person side, it is necessary to know who the actors are and how much attachment is based on individual or group meaning [15]. At the group level, attachment refers to the symbolic value of a location shared by its members [19]. Place attachment can also elicit recollections of a historical event or personal experiences [19].

The process side will bring the psychology aspect, so it can be identified precisely how the influence of emotions/feelings, cognitions, and action manifests in attachment [15]. Sadness might be triggered by the loss of a place that has left an indelible mark on the heart. For example, there will be memories of a prior location, and some of them may be realized again in a new one. Meanwhile, memories, beliefs, meanings, and knowledge are all part of cognition.

Lastly, a place will bring interaction to the social domain through its symbols in the physical environment, which includes both the natural and artificial environments.

\subsection{The Origin of Gapura}

Gapura can be translated as a huge entrance that leads into the yard. During the Hindu-Buddhist period, Gapura was also known as the gate building [20]. Thus, it can be said that Gapura is the architecture that refers to the gate or the entry of the location/building.

Gapura was commonly found in temples and other Hindu holy locations. Thus, it is considered one of the essential aspects of Hindu architecture. Dawara, dwara and bapra were Sanskrit words for gates in the Hindu era. A dwarapala/dwarapati, or gatekeeper statue, is also commonly found in dwara. While the term Gapura was introduced after the influence of Islam.

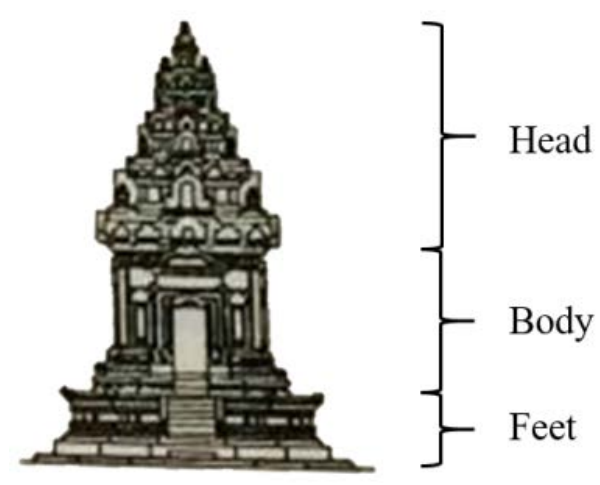

Figure 2. Temple’s architecture

Gapura can be classified as a temple due to its similar architecture. The temple architecture can be identified as head, body, and legs, as depicted in Figure 2 [21].
The head of the temple represents the heavenly realm where Gods and souls gained perfection. In general, the head of the temple is divided into three levels, where the highest position has the smallest size. The head style of the temple in East Java consists of many levels. This level creates a perspective illusion, which makes the structure look taller than its actual size. A crown in the shape of a wajra, ratna, stupa, or lingga semu is generally found at the peak of the roof.

The head of the temple is also known as mustaka, kemuncak, or mastaka. Antefix ornaments, or ornaments with three-pointed sections, are commonly used to embellish the corners and center of the roof. However, the walls id left to be plain in some small temples.

The body of the temple is the central component and is usually shaped like a cube which represents bhuwarloka or the realm in between. This section shows the role of the holy man who seeks inner perfection and enlightenment. A kala head is commonly carved in the middle of the entrance, bordered on both sides by a makara pattern. Furthermore, there are narrative or ornamental reliefs with plant, animal, or human ornamentation on parts of the body.

The lowest portion of the temple is known as the foot. The underworld, or bhurloka, is symbolized by this portion. This section portrays the world of ordinary humans who are still bound by low lust and the realm of animals and spirits such as giants, demons, and asuras. The foot of the temple is usually square-shaped with a ladder on one side and located in the entrance stair. The wall at the foot of the temple usually features a relief of wildlife and flora in the form of plant tendrils or guardian figures like dwarapala in specific temples.

The architecture of the Majapahit Era has a combination style of Javanese and Hindu. It can be found in Trowulan, Mojokerto, and the surrounding area. Gapura can be divided into two types based on architectural form and location, such as bentar/belah and paduraksa [22]. For example, the Bajang Ratu temple and the Wringin Lawang temple.

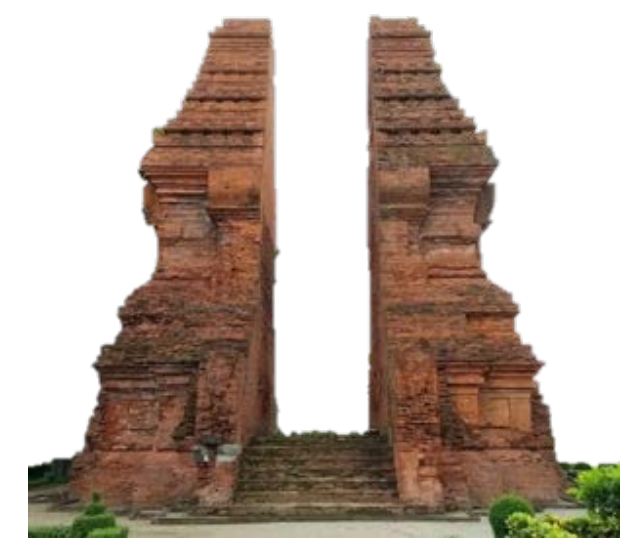

Figure 3. Wringin Lawang Temple

Figure 3 shows the Wringin Lawang temple, which belongs to the Bentar temple (divided into two) group and 
acts as the exterior gate of a temple or other structure [23]. The characteristic of this temple is always included high and terraced legs, a slender design, a cube-shaped peak on the roof, and slightly raised reliefs, and pictures/symbols on the walls that represent kingdom symbols [24].

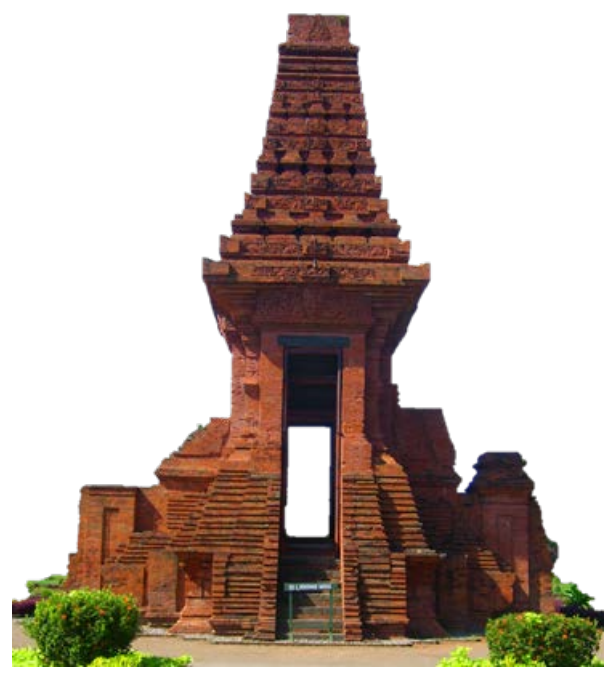

Figure 4. Bajang Ratu Temple.

Furthermore, the Bajang Ratu Temple, which is used as the back door of the kingdom, is depicted in Figure 4. The Bajang Ratu temple is shaped like a bentar temple with a paduraksa that connects the top and roof. Paduraksa means "entry into a sacred or exceptional place" [24].

Local wisdom is used in the process of preaching Islam by Sunan Ampel, which is shown by the culture and architecture of the mosque. For example, the Gapura of the mosque and the surrounding in Ampel Street [1]. In general, the basic form of the five Gapuras of the Sunan Ampel Mosque is similar to the temple architecture during the Majapahit kingdom, with the similarities as follows:

- Having Paduraksa temple form

- The head of the gate has a combination of levels with a cube-shaped top

- The body of the gate is slender

- There are several ornaments on the head and body of Gapura

Five Gapuras of the Sunan Ampel Mosque do not have many multi-level foot parts and are only dominant on the body and head, which is one of the most noticeable contrasts. The existence of multiple traps at the foot of the temple indicates that there is no caste divide in Islam, as there is in Hinduism. These five Gapuras have an average height of five meters.

Curves, parallel lines, spirals, secant lines, and other geometric shapes are found in the five Gapuras of the Sunan Ampel Mosque when viewed from the elements that make up the body of the Gapura. This design can also be seen in Hindu temples. These patterns, according to Fritz [21], are the outcome of human intelligence and illustrate the interaction between humans and the universe.
Furthermore, the green color has its meaning in the Gapura. According to Purnengseh [20], the green color in the sense of décor is a magical color that is thought to repel rage and anger. Green is also a sign of the garden of heaven in Islam and a symbol of harmony in Javanese society [9].

It implies that the Javanese-Hindu architecture of Majapahit, who was in charge, affected the shape of five Gapuras in Sunan Ampel Mosque. The symbols on the Gapura still obey the symbols of Majapahit laws but have been tweaked and reinterpreted to reflect Islamic culture. It is most likely motivated by the desire to avoid disputes between Hinduism and Islam and the risk of culture shock. The new Muslims will perceive little difference between Islam and their previous religion.

According to place attachment theory, efforts to reintroduce the previous identity embedded in people's lives will prevent the community from losing its orientation and identity, particularly due to the conversion from Hinduism to Islam [25]-[27]. People believe they are still living in the same socio-cultural context as before, with the same emotions/feelings [15].

There were no human or animal forms discovered at the Gapura of Sunan Ampel Mosque environment. All of the ornaments are square and geometric, with vegetation in flowers with eight crowns and tendrils. It can be traced back to Islamic beliefs, which prohibit both animal and human forms. Furthermore, the Prophet Muhammad declared in the Hadith given by Muslims and Bukhari that those who draw these depictions (of animate animals) will be chastised on the Day of Resurrection and that they will be told, "Live what you have created." Plant motifs, on the other hand, have been commonly used from prehistoric times since they are seen to represent a symbol of the world's transition [21].

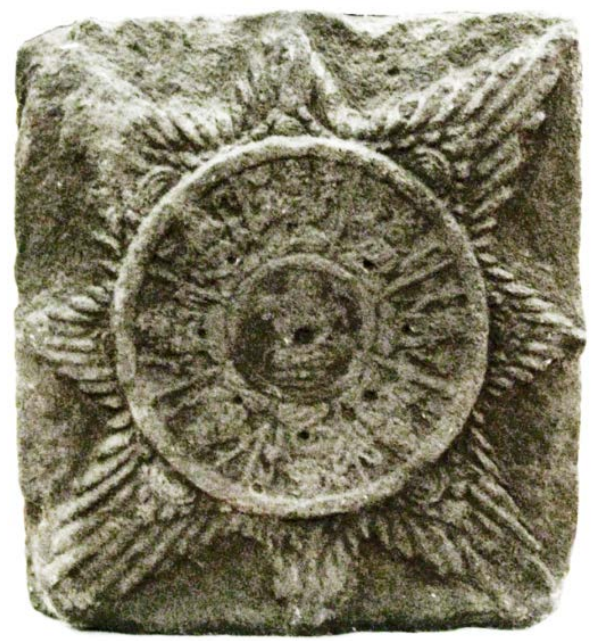

Figure 5. Surya Majapahit’s carving [10].

The symbols on the five Gapuras indicate the strong relationship/bond between the Sunan Ampel Mosque and the Majapahit through stylization or the elaboration of the ornaments based on the Surya Majapahit symbol kingdom. 
In other words, despite their opposing religions, Sunan Ampel and the King of Brawijaya have a peaceful relationship. The goal of the Majapahit ornament in the Ampel Mosque, according to Zeid in Kusumo [1], is to honor the king of Majapahit. In addition, various royal symbols can be discovered on the Gapura of Sunan Ampel Mosque, including the following:

- A great number of bloom buds indicate a plentiful supply of seeds and prosperity.

- Surya Wilwatikta, which means strength and victory, is the Majapahit kingdom's symbol.

- The flower crown includes eight acute angles, representing the number of cardinal directions in Javanese Hindu teachings or 16 rays on the Surya Majapahit symbol, as depicted in Figure 5.

\subsection{Sunan Ampel}

Sunan Ampel, also known as Raden Rahmat Ali Rahmatullah, is a Walisongo born in Champa, Cambodia. Sunan Ampel is the son of the first Walisongo, Maulana Malik Ibrahim, which is known as Ibrahim Asmoroqondi or Sunan Gresik [6]. Sunan Ampel is the first Walisongo who has a trace in spreading Islam in Java.

In 1420, Snan Ampel moved to East Java, the capital of Majapahit Kingdom, and taught about Islam to the Hindu beliefs. Because Sunan Ampel was close with Sri Brawijaya, King of Majapahit, he was lent a place called Ampel Denta. As additional information, Ampel is derived from the Javanese term ngampil, which means "to borrow" [1].

In 1450, Sunan Ampel constructed and developed a mosque in the Ampel Denta area [7]. The mosque was built with the help of the relative of Sunan Ampel, such as Mbah Bolong, Mbah Sholeh, and other students. The students of Sunan Ampel come from all over the country, from the nobility and also ordinary people. Sunan Giri, Sunan Bonang, Sunan Drajat, and Raden Patah/Sunan Kota [8] were the well-known students of Sunan Ampel. Sunan Ampel died in 1478 AD and was buried in the west of the Sunan Ampel Mosque.

\subsection{Gapura in the Sunan Ampel Mosque Environment}

The word Gapura is derived from the Arabic word "Ghafura," which implies forgiveness. This word is a part of Asmaul Husna (The 99 good names of Allah). There are five unique Gapuras in Sunan Ampel mosque, such as Paneksen, Madep, Ngamal, Poso, and Munggah. All of the Gapuras names are taken from the Javanese language.

Figure 6 illustrates the gate arrangement in the Sunan Ampel mosque environment, which can be observed from the inside to the outmost of the mosque environment. The gates are divided into two groups, one on the south side with two gates and the other on the west side with three gates.

There are two gates to enter or leave the mosque neighborhood, namely the Madep Gapura (number 2) on the west side and the Poso Gapura (number 4) on the south side. Madep Gapura, which means facing, is interpreted as facing God by praying, which is the second pillar of Islam. This Gapura is located on the west side, which means the direction of Muslims while praying, face the Kaaba. Poso Gapura is the reminder for Muslims for fasting during Ramadhan month, as said in the Pillar of Islam number three. Both of the Gapuras represent the most fundamental things for Muslims, such as praying and fasting. Thus, all of the people who walk through these two Gapuras will be reminded to pray and fasting.

There are three Gapuras which are not directly lead to the mosque, Munggah Gapura (number 5), Ngamal Gapura (number 3), and Paneksen Gapura (number 1). Munggah Gapura can be reached after walking pass through Poso Gapura. It can be interpreted as after doing fasting, Muslims must go to Baitullah in Mecca as the fifth Pillar of Islam if they fulfill the requirement, which is good physical, psychological, and financial. Furthermore, only Munggah Gapura has traps, which strengthens the word "Munggah".

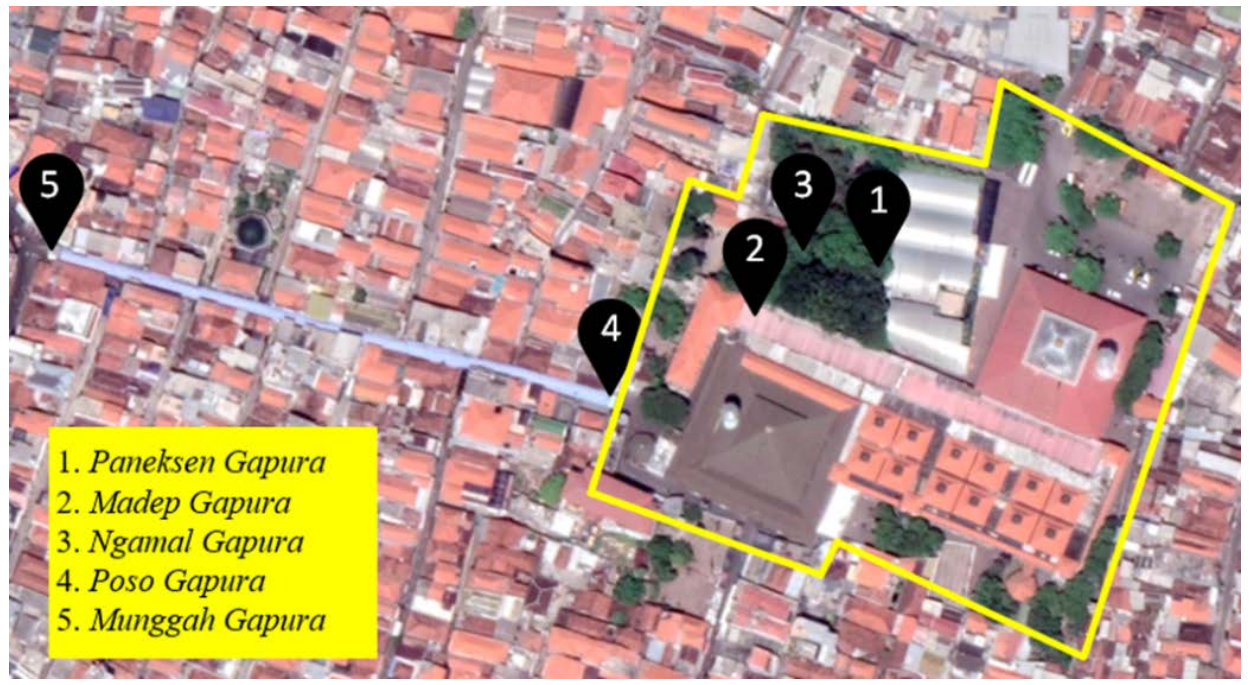

Figure 6. The location of Gapura in Sunan Ampel neighborhood 
Furthermore, Ngamal Gapura, as the third Pillar of Islam, can be reached from Madep Gapura. Muslims must take care of each other, which means giving the zakat or charity to the needs. After that, the Paneksen Gapura can be reached after walking passed through the Ngamal Gapura, which means the creeds for the Muslim.
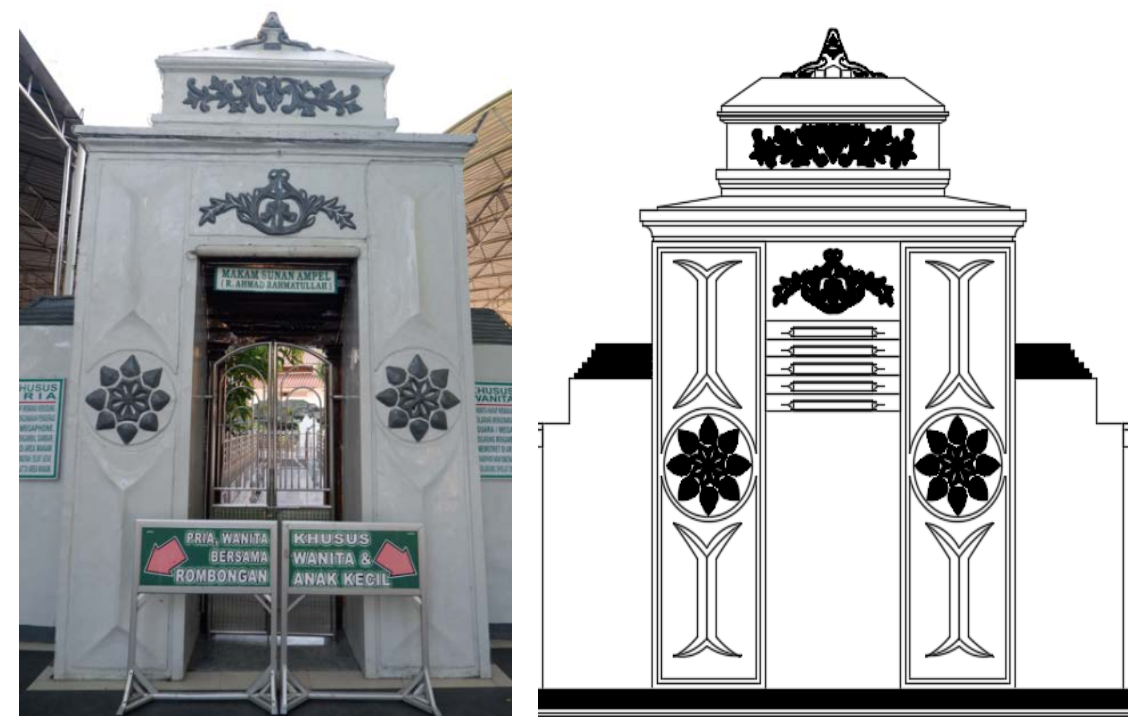

Figure 7. Paneksen Gapura

Table 1. The ornament of Paneksen Gapura

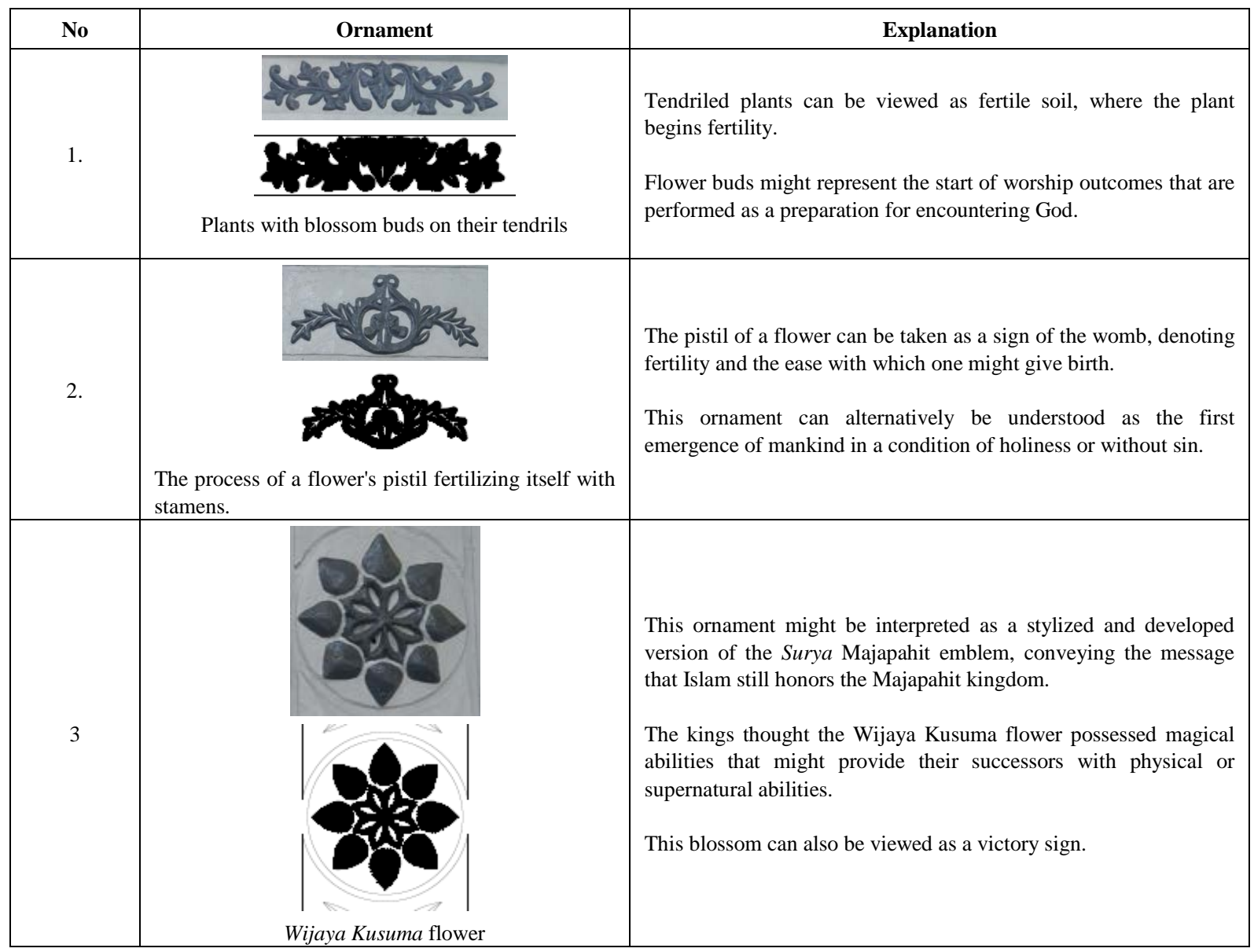

It can be seen that the name of the Gapura Thus, society, especially Muslims, will always remember the Pillar of Islam. In addition, it reminds the Muslim to always follow the Pillar of Islam as the guidance of Prophet Muhammad in the daily activity. 
The first Gapura is Paneksen Gapura which is shown in Figure 7. This Gapura is led into the grave of Sunan Ampel. While the meaning of Paneksen Gapura is "witness", where comes from two sentences of creeds "I bear witness that (there is) no God except Allah, and I bear witness that Muhammad is the messenger of Allah.”. These creeds are usually an open door or the beginning if someone wants to be a Muslim. In addition, the ornament in Paneksen Gapura has a significant meaning, as shown in Table 1.

The Madep Gapura, as depicted in Figure 8, is the second Gapura in Sunan Ampel Mosque. Madep means "facing" in Javanese. The objective of facing is to pray to God while facing the Baitullah, as Muslims do. This Gapura is on the west of the mosque and is the only one that faces west, precisely facing the Kaaba. Mbah Sonhaji (Mbah Bolong), who assisted in determining the direction of Qibla during the construction of the Sunan Ampel Mosque, is buried in the right of Madep Gapura. The interpretation of Madep Gapura is the prayer time for Muslims, which is five times a day (Fajr, Zuhur, Asr, Maghrib, and Isha). Moreover, the ornament and explanation of the Madep Gapura are explained in Table 2.
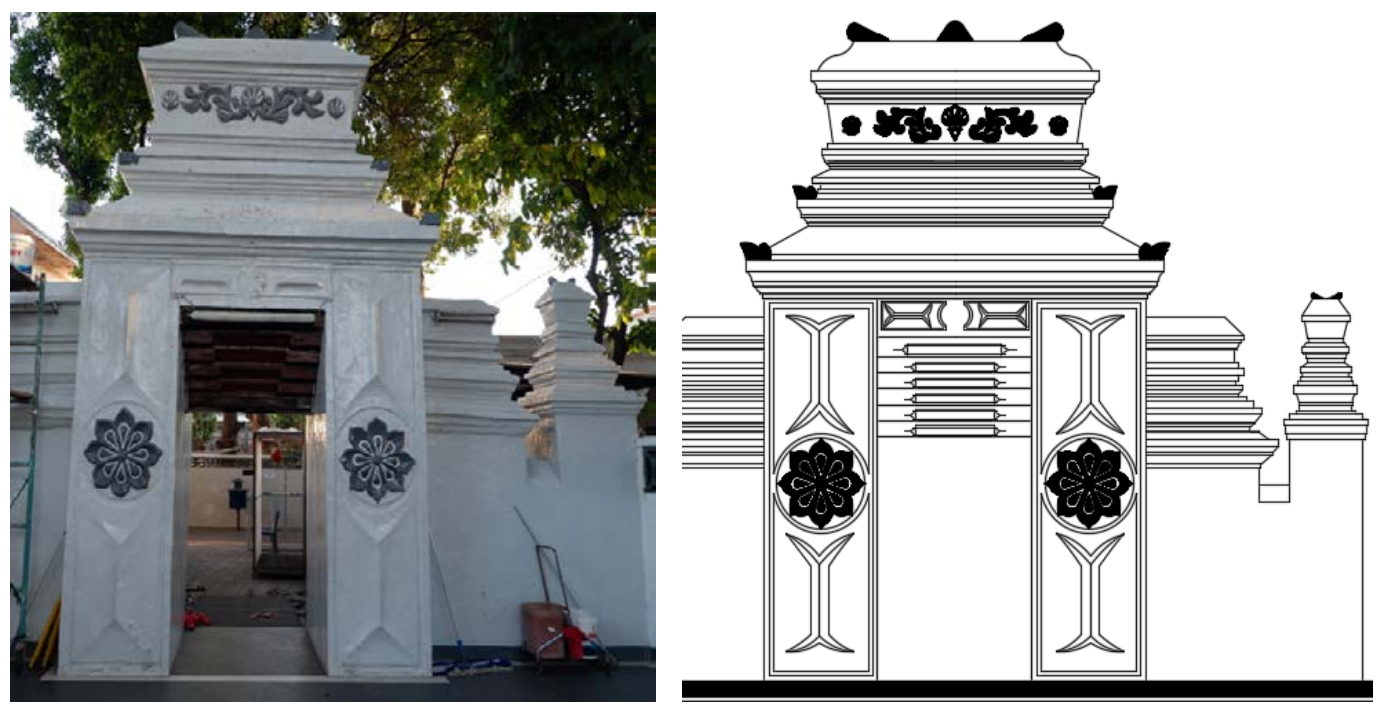

Figure 8. Madep Gapura

Table 2. The ornament of Madep Gapura

\begin{tabular}{|l|l|}
\hline No & \multicolumn{1}{|c|}{ Explanation } \\
\hline 2. & $\begin{array}{l}\text { Blooming flowers denote a period of glory or success. } \\
\text { As a result of praying for people who carry out, plants that grow and } \\
\text { blooming will smell wonderful in the west. }\end{array}$ \\
\hline Flowers with 16 crowns in each arrangement, \\
two layers of eight crowns each.
\end{tabular}


Ngamal Gapura, the third gate in Sunan Ampel Mosque, is shown in Figure 9. The location of Ngamal Gapura is on the southwest side of the mosque. The interpretation of this Gapura is "to give a charity and zakat" to the other people in need. Table 3 shows the explanation of the ornament from Ngamal Gapura.
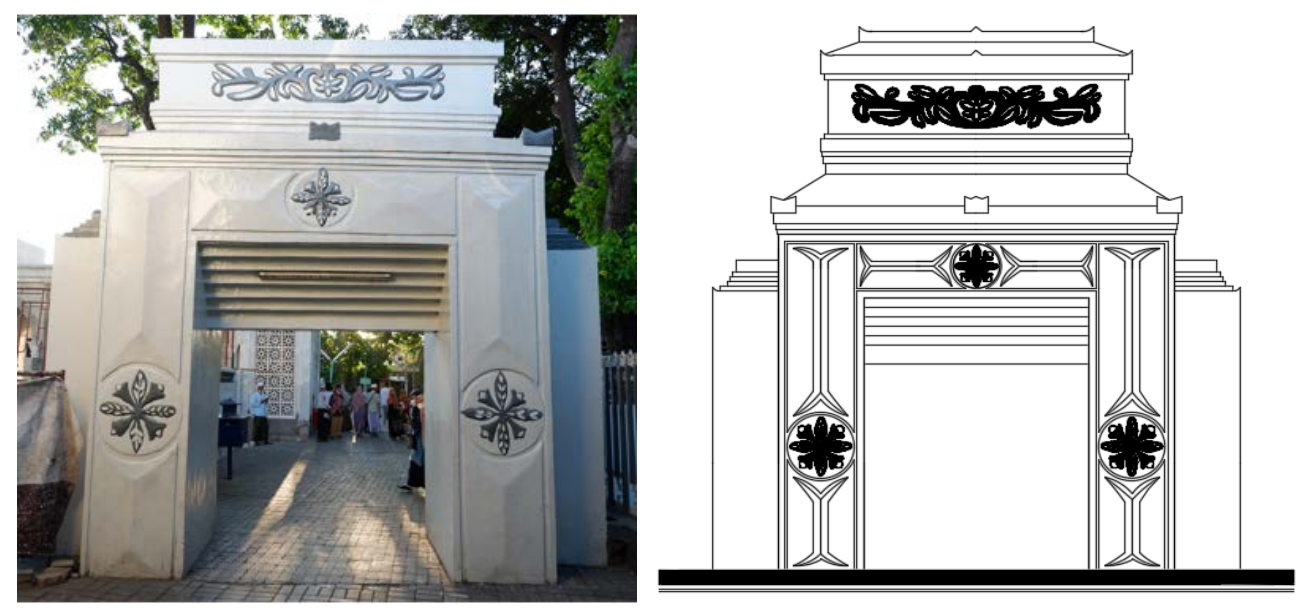

Figure 9. Ngamal Gapura

Table 3. The ornament of Ngamal Gapura

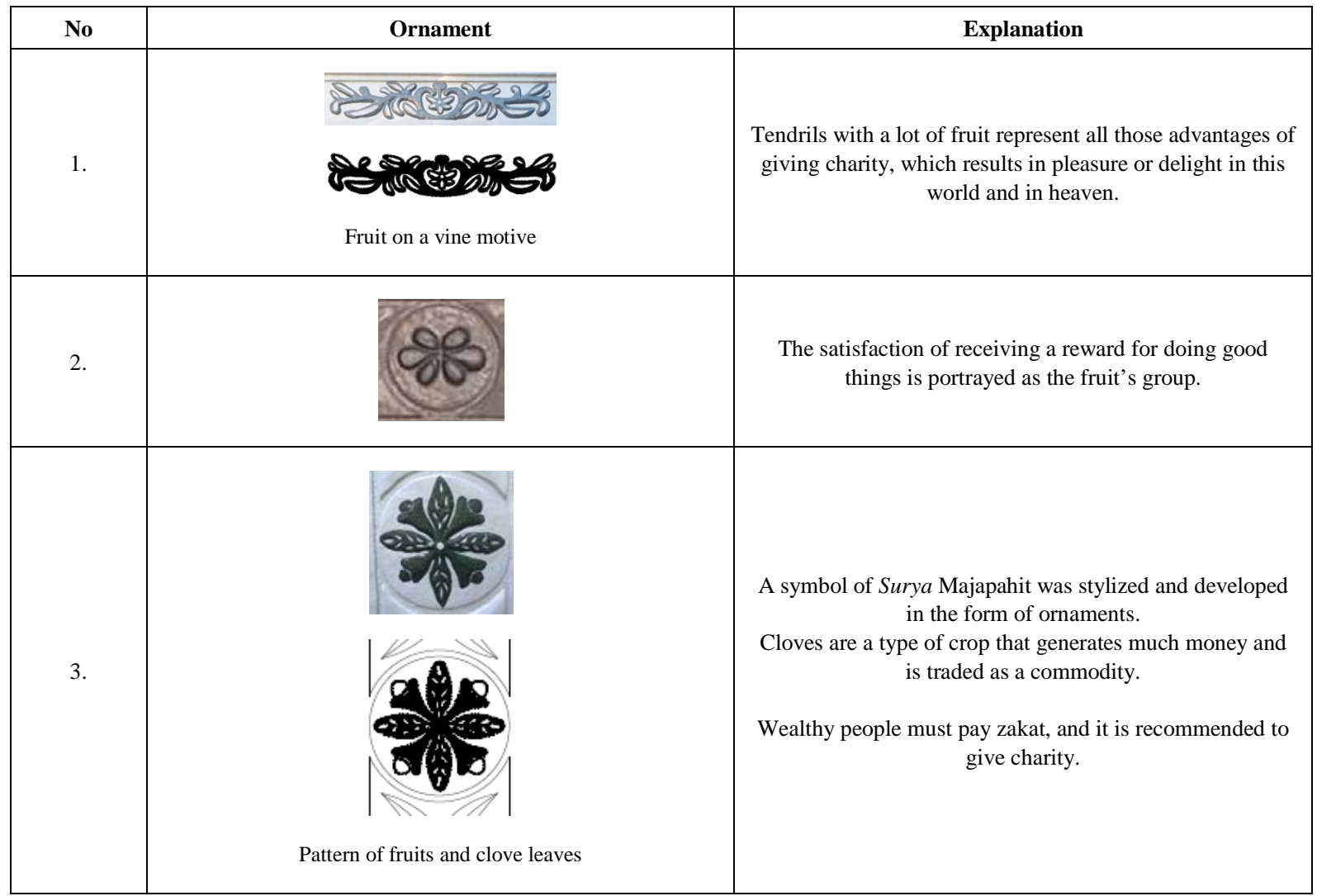


The fourth Gapura is Poso Gapura which determines the activity of Muslims, "fasting". The Poso Gapura, shown in Figure 10, shows that Muslims are prohibited from eating, drinking, and engaging in some activity from dawn to sunset during a fasting activity, especially in Ramadhan month. Fasting during Ramadhan is an excellent opportunity for Muslims to ponder, bow down, and pray. Poso Gapura can be seen from the south of Ampel Street after passed the villager hallway. Furthermore, Table 4 describes the ornament and the explanation of the Poso Gapura.

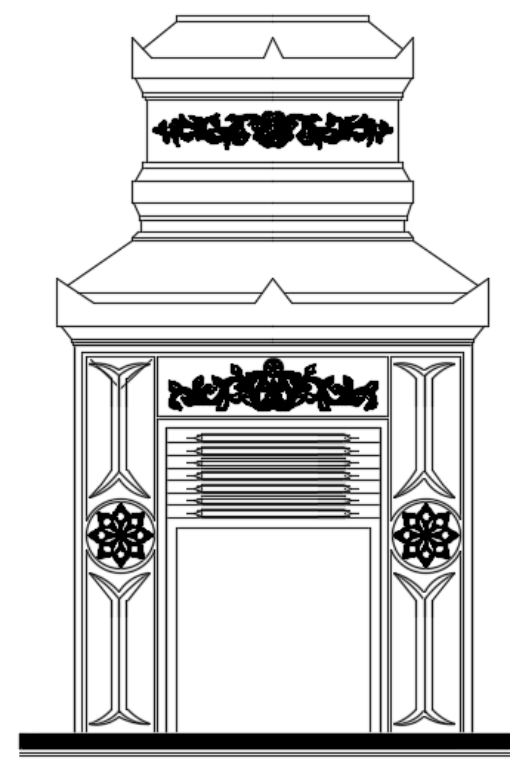

Figure 10. Poso Gapura

Table 4. The ornament of Poso Gapura

\begin{tabular}{|l|l|l|}
\hline No & \multicolumn{1}{|c|}{ Explanation } \\
\hline A flowering plant having a large number of blossom buds. & $\begin{array}{l}\text { Flowers that are still buds can be seen as an early sign of } \\
\text { kindness emitted from the fasting results, and that } \\
\text { maintains the life journey. }\end{array}$ & $\begin{array}{l}\text { The large flower in the middle, flanked by tendrils, } \\
\text { represents the tremendous reward and benefits of fasting. }\end{array}$ \\
\hline 2. & $\begin{array}{l}\text { This ornament is essentially the consequence of the Surya } \\
\text { Majapahit stylization symbol and evolution. } \\
\text { The only ornament in a closed flower shape to protect the } \\
\text { center of the flower represents the human predicament } \\
\text { during fasting. It happens when someone closes or refrains } \\
\text { from the behaviors that could break the fast. }\end{array}$ & \begin{tabular}{l} 
Flowers with a three-stack crown \\
\hline
\end{tabular}
\end{tabular}


The last Gapura in Sunan Ampel mosque is Munggah Gapura. This Gapura means the rise or ascends, as shown in Figure 11. Ascend can be interpreted to make the pilgrimage to Baitullah if capable. Hajj is a religious pilgrimage to Mecca's sacred land and a must for Muslims who are good in physical, psychological, and financial. Munggah Gapura is the outermost of the Gapura, precisely on Sasak street. Moreover, Table 5 shows the explanation of each ornament in Munggah Gapura.
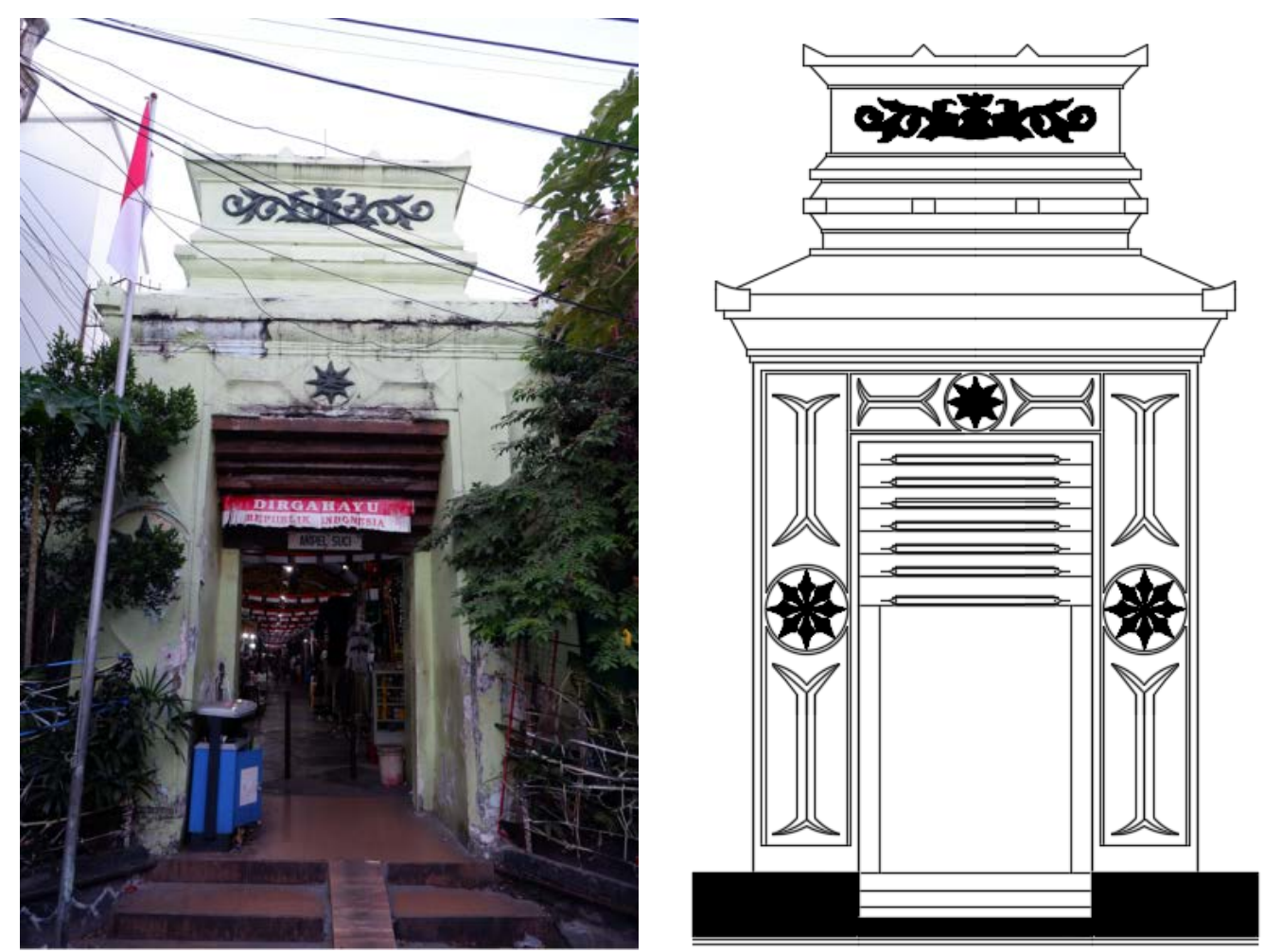

Figure 11. Munggah Gapura

Table 5. The ornament of Munggah Gapura

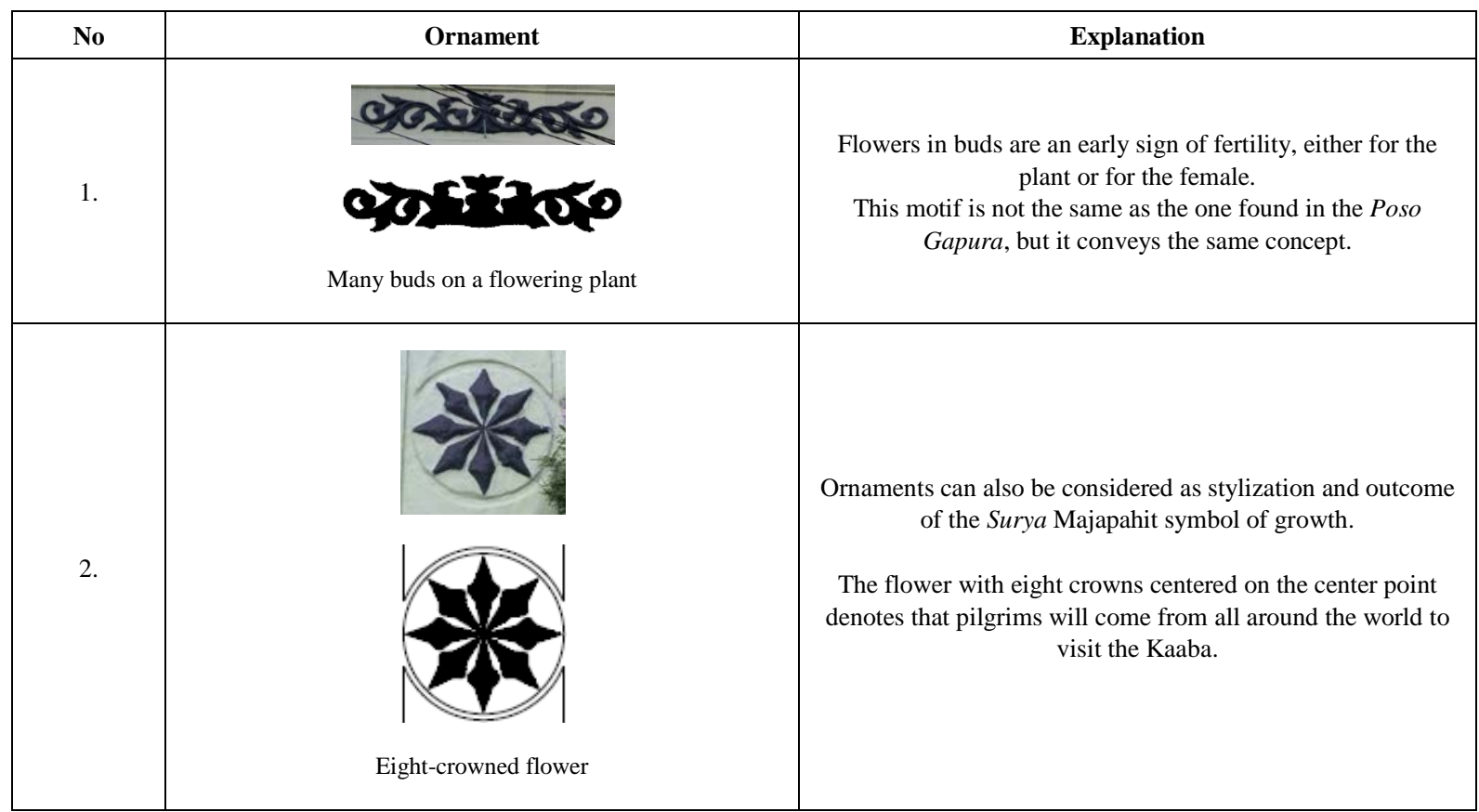


During Era Sunan Ampel, the primary entrance to the Sunan Ampel mosque area is from Munggah Gapura. Sasak street is chosen as the main street of the mosque because the other street is the main route of shipping to Majapahit kingdom, which is very crowded and noisy. Thus, the school remains silent and tranquil, which is good for learning and praying. Furthermore, the neighborhood is also a little bit far away from the main road to keep it settled, but it has convenient access to the city center and the transportation route.

\section{Conclusions}

The architecture of the building and the ornament are always attached to society. For example, the Gapura in Sunan Ampel neighborhood has many memories for Muslims in Surabaya about the beginning of Islam in Surabaya. The similarity of Gapura and the temple's architecture shows that Sunan Ampel tries to connect the impression from the past and combine it with the present condition. It is in line with the place attachment theory that place attachment can be used to remember the historical place or evoke someone's memories towards a place.

Furthermore, the name of the Gapura is suitable with the Pillar of Islam which has five Pillar, such as Paneksen Gapura, Ngadep Gapura, Ngamal Gapura, Poso Gapura and Munggah Gapura. Moreover, Gapuras in the Sunan Ampel neighborhood shows the typical ornament from the Majapahit Era but with a slight addition of Pillar of Islam. As a result, society does not feel drastic changes and is happily welcoming the new conditions. It is proven by the massive development of Islam in Java at that time. Due to the present study only focus on the thought of Sunan Ampel when building the Gapuras, further research is needed to know the thought of the people nowadays about the presence of Gapuras.

\section{REFERENCES}

[1] Eko Sulistyo Kusumo, "Bentuk Sinkretisme Islam-Jawa di Masjid Sunan Ampel Surabaya,” Mozaik Humaniora, vol. 15, no. 1, pp. 1-13, 2015. https://e-journal.unair.ac.id/MOZ AIK/article/view/3847

[2] Badan Pusat Statistik, poster "Hasil Sensus Penduduk 2020," https://www.bps.go.id/galeri (accessed July 20, 2021)

[3] Achmad Fawaid, "Pilgrimage to Sunan Ampel: From “Comunitas” to Contested Space,” Jurnal Al-Turas, vol. XX, no. 1, pp. 55-67, 2014. DOI: 10.15408/bat.v20i1.3747

[4] Imam Santoso, Bambang Setyoko, Edward E. Pandelaki, "Simbolisasi/Penandaan Masjid Sebagai Suatu Identitas pada Kawasan: Pandangan pada Masjid Sunan Ampel Surabaya Jawa Timur-Indonesia," The $2^{\text {nd }}$ ECO-Arcitechture Conference (EAC 2), Wonosobo City,
Central Java, Indonesia, April 6-7, 2015. pp. 318-325. https://docplayer.info/46583409-Simbolisasi-penandaan-m asjid-sebagai-suatu-identitas-pada-kawasan-pandangan-pa da-masjid-sunan-ampel-surabaya-jawa-timur-indonesia.ht $\mathrm{ml}$

[5] Anas Muhammad, Isa Sani Mohammed, Aisha Wali Aminu-Umar, "Elements of Architectural Design and Interpretation of Buildings and Monuments in Kaduna State," Civil Engineering and Architecture, vol. 6, no. 4, pp. 181-188, 2018. DOI: 10.13189/cea.2018.060401

[6] Ashadi, "Dakwah Wali Songo Pengaruhnya Terhadap Perkembangan Perubahan Bentuk Arsitektur Mesjid di Jawa,” Jurnal Arsitektur NALARs, vol. 12, no. 2, pp. 1-12, 2013. https://jurnal.umj.ac.id/index.php/nalars/article/view /573/534

[7] Wiryoprawiro M. Z, "Perkembangan Arsitektur Masjid di Jawa Timur,” Surabaya, Bina Ilmu, 1986.

[8] Ashadi, "Perkembangan Arsitektur Mesjid Walisongo di Jawa: Perubahan Ruang dan Bentuk," Jurnal Arsitektur NALARs, Vol. 11, no. 2, pp. 143-160, 2012 https://jurnal.umj.ac.id/index.php/nalars/article/view/587

[9] Nurin Aldina, Antariksa, Wulan Astrini, "Ekspresi Sakral Arsitektur pada Bangunan Masjid Sunan Ampel Surabaya," Brawijaya University, Jurnal Arsitektur, vol. 5, no. 4, 2017. http://arsitektur.studentjournal.ub.ac.id/index.php/jma/artic le/view/422

[10] Adisukma. Wisnu, "Melacak Makna Konsep Keserupaan pada Lambang Instansi di Indonesia dengan Sumber Bentuk Matahari (Studi Kasus Perkembangan Bentuk Surya Majapahit),” Brikolase, vol. 11, no. 2, pp. 206-225, 2019. DOI: $10.33153 /$ brikolase.v11i2.2908

[11] Ningroom Adiani, “Telaah Ornamen Gapura dan Masjid Ampel Sebagai Kekhasan Lokal untuk Meningkatkan Nilai Estetik Souvenir,” Seminar Nasional Sains dan Teknologi Terapan III, Surabaya, Indonesia, October 13, 2015. pp. 687-704.https://jurnal.itats.ac.id/wp-content/uploads/2015/ 10/14.-ningrum.compressed.pdf

[12] Deniz Cakar, Mujgan Karatosun, "Effects of Cittaslow Movement on Conservation of Cultural Heritage: Case of Seferihisar \& Halfeti, Turkey," Civil Engineering and Architecture, vol. 5, no. 3, pp. 71-82, 2017. DOI: 10.13189/cea.2017.050301

[13] Giuliani M. V, “Theory of Attachment and Place Attachment,” Bonnes, M. Lee T and Bonaiuto M Eds., Psychological Theories for Environmental Issues, Ashgate, Aldershot, 2003. Pp. 137-170.

[14] https://www.researchgate.net/publication/228091197_Theo ry_of_Attachment_and_Place_Attachment_In_M_Bonnes _T_Lee_and_M_Bonaiuto_Eds_Psychological_theories_fo r_environmental_issues.

[15] I. Altman, "Place Attachment: A Conceptual Inquiry," I. Altman, Low Eds., Human Behavior and Environment: Advances in Theory and Research vol 12, New York, Plenum Press, 2003. pp. 1-12.

[16] Leila Scannell, Robert Gifford, "Defining Place Attachment: A Tripartite Organizing Frame-work," Journal of Environmental Psychology, vol. 30, no. 1, pp. 1-10, 2010. DOI: 10.1016/j.jenvp.2009.09.006 
[17] Greg Brown, Jonathan Corcoran,. Raymond C. M, “Mapping and measuring place attachment," Jurnal aplied geography vol. 57, pp. 42-53, 2015. DOI: 0.1016/j.apgeog.2014.12.011

[18] Charis E. Anton, Carmen Lawrence, “The relationship between place attachment, the theory of planned behaviour and residents' response to place change,” Journal of Environmental Psychology, vol. 47, pp. 145-154, 2016. DOI: 10.1016/j.jenvp.2016.05.010

[19] A. Rapoport, "The Meaning of the Built Environment, a Nonverbal Communication Approach," Tucson, The University Arizona Press, 1990.

[20] Bog aç, Ceren. Place attachment in a foreign settlement. Journal of Environmental Psychology Vol 29, pp 267-278, 2009. DOI: 10.1016/j.jenvp.2009.01.001

[21] Iis Purnengsih, Umi Kholisya, "Representasi Kosmologi Jawa pada Gapura Kontemporer di Desa-Desa Kabupaten Karanganyar,” Cakrawala-Jurnal Humaniora, vol. 19, no. 1, pp 113-120, 2009. https://ejournal.bsi.ac.id/ejurnal/index.p hp/cakrawala/article/view/5032/3117

[22] Heinz Frick, "Pola Struktural dan Teknik Bangunan di Indonesia,” Yogyakarta, Kanisius, 2001.

[23] Widisono, Yusfan Adeputra Yusran, Antariksa, "Karakter Visual Gapura Wringin Lawang pada Gapura di Perbatasan
Kota Malang,” Langkau Betang, vol. 5, no. 2, pp. 109-121, 2018. DOI: 10.26418/lantang.v5i2.30134

[24] Ninik Juniati, Tjiptawan Ardeliah, "Gapura Wringin Lawang Sebagai Ide penciptaan Karya Seni Macrame," Jurnal ATRAT, vol. 7, no, 3, pp. 262-268, 2018. https://jurnal.isbi.ac.id/index.php/atrat/article/view/971

[25] Eni, Sri Pane, Adjeng Hidayat Tsabit, “Arsitektur Kuno Kerajaan-kerajaan Kediri, Singasari, dan Majapahit di Jawa Timur Indonesia,” Jakarta, Rajawali Pers, 2017. https://opac.perpusnas.go.id/DetailOpac.aspx?id=1137220

[26] Norsidah Ujang, Khalillah Zakariya, “Place Attachment and the Value of Place in the Life of the user," Procedia Social and Behavioral Sciences, vol. 168, pp. $373-380$, 2014. DOI: 10.1016/j.sbspro.2014.10.243

[27] Shampa Mazumdar, Sanjoy Mazumdar, "Religion and place attachment A study of sacred places,” Journal of Environmental Psychology, vol 24, no. 3, pp. 385-397, 2004. DOI: 10.1016/j.jenvp.2004.08.005

[28] Mina Najafi, Mustafa Kamal Bin Mohd Sharaiff, "Public Attachment to Religious Places A Study of Place Attachmentto Mosques in Malaysia,” International Journal of Social, Behavioral, Educational, Economic, Business and Industrial Engineering, vol. 8, pp. 284-295, 2014. DOI: 10.5281/zenodo.1090719 